\title{
Inheritance of Resistance to Stagonospora nodorum Leaf Blotch in Kansas Winter Wheat Cultivars
}

\author{
Yong-ki Kim, Department of Plant Pathology, Kansas State University, Manhattan 66506; Gina L. Brown-Guedira, \\ United States Department of Agriculture-Agricultural Research Service, Kansas State University, Manhattan 66506; \\ Thomas S. Cox, The Land Institute, Salina, KS 67401; and William W. Bockus, Department of Plant Pathology, \\ Kansas State University
}

\begin{abstract}
Kim, Y. K., Brown-Guedira, G. L., Cox, T. S., and Bockus, W. W. 2004. Inheritance of resistance to Stagonospora nodorum leaf blotch in Kansas winter wheat cultivars. Plant Dis. 88:530-536.

Stagonospora nodorum blotch can cause serious yield and quality losses of wheat (Triticum aestivum) in many countries worldwide. Although there are other control methods, host resistance is the most desirable. Three recent Kansas winter wheat cultivars (Betty, Heyne, and 2163) have been developed with moderate levels of resistance to the leaf phase of Stagonospora nodorum blotch. To determine inheritance of resistance and allelism, these cultivars were crossed with one of three susceptible lines (Larned, KS96WGRC39, or Newton) and intercrossed in all possible combinations, including reciprocals. The parents, $F_{1}, F_{2}$, and $F_{3}$ generations were tested for resistance to $S$. nodorum in the greenhouse as 4-week-old seedlings. Cytoplasmic effects were not detected in any cross. The mean levels of infection in the $\mathrm{F}_{1} \mathrm{~s}$ of the two crosses Betty $\times$ Larned and Heyne $\times$ KS96WGRC39 indicated resistance was dominant. The observed phenotypic ratios of $\mathrm{F}_{2}$ plants for both crosses were not significantly different from the expected ratio for a single dominant gene. The ratio observed for $\mathrm{F}_{3}$ lines in the Betty $\times$ Larned cross fit that expected for a single dominant gene. However, the observed ratio of the $\mathrm{F}_{3}$ lines from the cross Heyne $\times$ KS96WGRC39 did not fit the ratio expected for a single dominant gene. The allelism test for Betty and Heyne indicated that they have different resistance genes. The $\mathrm{F}_{1}$ mean rating of the cross $2163 \times$ Newton was intermediate between the two parents, indicating the absence of dominance for resistance in 2163 . The phenotypic ratio observed in the $F_{2}$ plants from this cross did not fit the ratio expected for a single dominant gene. The simple genetic control of resistance in cv. Betty makes it a useful source of resistance for wheat breeding programs.
\end{abstract}

Stagonospora nodorum blotch, caused by Stagonospora nodorum (Berk.) Castellani \& E.G. Germano (= Septoria nodorum (Berk.) Berk. in Berk. \& Broome, teleomorph: Phaeosphaeria nodorum (E. Müller) Hedjaroude) can cause serious yield and quality losses of wheat (Triticum aestivum L.) in many countries worldwide $(3,14,20)$. Yield losses caused by this disease have been reported as high as $40 \%$ in severe epidemics $(8,18,31)$. Under severe epidemics, the kernels of susceptible wheat cultivars are shriveled and are not fit for milling (11).

The fungus causes both leaf and glume blotch of wheat. Although glume blotch was stated to be the main cause of yield reduction $(16,18)$, foliar infection can be as

Corresponding author: W. W. Bockus

E-mail: bockus@plantpath.ksu.edu

Kansas Agricultural Experiment Station Contribution No. 04-142-J. This project was supported by the Kansas Wheat Commission and Kansas Crop Improvement Association.

Accepted for publication 5 January 2004.

Publication no. D-2004-0301-02R

(C) 2004 The American Phytopathological Society detrimental to yield as head infection (11). For example, Walther and Bohmer (34) reported that Stagonospora nodorum blotch severity on leaves had the highest correlations with yield loss, whereas head infection was poorly correlated with yield.

Although there are several control methods, including crop rotation and foliar fungicides, the preferred method of control is the use of resistant cultivars $(4,36)$. However, breeding for resistance to $S$. nodorum is difficult because resistance can be correlated with undesirable agronomic traits such as tall plant height and late maturity (32).

Resistance to the leaf and head phases may be under separate genetic control $(2,15,35)$. Fried and Meister (13) also reported evidence for independent segregation of genes controlling resistance to leaf and glume blotch. Resistant genes for reaction on the flag leaf were found on chromosomes $3 \mathrm{~A}, 4 \mathrm{~A}$, and $3 \mathrm{~B}$, while those for the head phase were located on the same

The testing of wheat seedlings in the greenhouse has been reported to be an effective strategy for identifying reactions to $S$. nodorum because the susceptibility of seedlings was correlated with that of the adult plants in the field $(10,20,28)$. This chromosomes and on 7A (15). type of testing permits use of quantitative inoculation techniques and eliminates the influence of undesirable agronomic traits such as tall plant height and late maturity on selection (37).

Many sources of resistance to Stagonospora nodorum blotch have been identified in species related to wheat: Triticum timopheevii $(23,33)$, T. monococcum (22), Aegilops tauschii (22,27), A. speltoides (5), and A. longissima (6). In addition, resistance also has been identified in several wheat cultivars and their genetic control studied. However, most studies were conducted for resistance to glume blotch and indicated that the resistance was polygenically controlled $(7,13,17,25,26,37)$. A few studies were undertaken to study resistance to leaf blotch. In recent studies, Wilkinson et al. (37) and Wicki et al. (35) reported that the resistance to the leaf phase is inherited polygenically in winter wheat cultivars commonly grown in the United States and Europe, respectively. However, Frecha (12) reported a single dominant gene for seedling resistance to Stagonospora nodorum blotch in the wheat $\mathrm{cv}$. Atlas 66. This gene was located on chromosome 1B (19). Wong and Hughes (38) also reported monogenic control for resistance to the leaf phase of Stagonospora nodorum blotch in three winter wheat cultivars (81IWWMN 2095, Coker 76-35, and Red Chief). In addition, Scharen and Eyal (30) provided evidence that resistance in highly resistant cultivars might be governed by major resistance genes. Although simple inheritance of resistance to leaf blotch has been reported, use of the resistance has lagged because of lack of supporting reports for additional single-gene resistances. The reason for failure to identify other resistances controlled by single genes is because many studies were conducted in the field where other foliar diseases may confound disease ratings.

In recent years, several winter wheat cultivars adapted to Kansas have been released with improved resistance to the leaf phase of Stagonospora nodorum blotch (1). These were developed by recurrent-selection for green leaf duration in numerous field nurseries during the breeding period. These cultivars have been grown extensively in Kansas with one cultivar (Jagger) occupying $43 \%$ of the seeded acreage in 2002. Because of their 
commercial importance and usefulness as sources of resistance to Stagonospora nodorum blotch, it would be desirable to know more about the inheritance of resistance in these cultivars. The objective of this study was to determine the number of genes controlling resistance to the leaf phase of Stagonospora nodorum blotch in selected Kansas winter wheat cultivars and to identify whether the cultivars have the same or different genes for resistance.

\section{MATERIALS AND METHODS}

Plant material. Three winter wheat cultivars with moderate resistance to the leaf phase of Stagonospora nodorum blotch and three susceptible lines were selected based on their observed reaction in the field and results from preliminary experiments in the greenhouse. Their reaction in the greenhouse was further quantified during the time it took to produce $\mathrm{F}_{2}$ and $\mathrm{F}_{3}$ seed. Crosses involving several resistant parents usually are made using the same susceptible parent. However, we did not do this because, at the beginning of our experiments, we were not sure of the relative usefulness of our susceptible parents for a greenhouse inheritance study. In retrospect, Larned would have been the best choice for greenhouse inheritance studies because of its more uniform distribution of highly susceptible plants (Table 1). The moderately resistant cultivars were crossed with one of three susceptible lines and intercrossed in all possible combinations, including reciprocals, to examine the significance of reciprocal effects. Certified seed of all cultivars was used to make a total of 12 crosses (Table 2). Cv. Betty was included instead of Jagger because it is a sister line of Jagger and a newer release. The $F_{1}$ progenies of the 12 crosses were selfed to produce $\mathrm{F}_{2}$ generations. $\mathrm{F}_{3}$ lines were obtained from 192 and $128 \mathrm{~F}_{2}$ plants of Betty $\times$ Larned and Heyne $\times$ KS96WGRC39 crosses, respectively. In each generation, seed were sown in small square pots ( 5 by 5 by $4 \mathrm{~cm}$ ). After 7 to 10 days, the seedlings were vernalized for 7 to 8 weeks in a growth chamber $\left(4^{\circ} \mathrm{C}\right)$ before being transplanted into larger pots (15.5$\mathrm{cm}$ top diameter, $13-\mathrm{cm}$ bottom diameter, and $15.5 \mathrm{~cm}$ tall) containing pasteurized soil (Kennebeck silty clay loam) in the greenhouse.
The $F_{1}$ plants were tested for resistance to assess dominance, and the $\mathrm{F}_{2}$ plants and $\mathrm{F}_{3}$ lines were tested to determine the phenotypic ratios, which were used to estimate the number of genes controlling resistance. For testing, seed of $F_{1}, F_{2}$, and $F_{3}$ generations, and their parents, were placed on moistened filter paper (Whatman no. 1) in petri dishes and incubated at room temperature for 3 to 4 days to synchronize germination. One germinated seed was planted in a plastic tube $(2.5 \mathrm{~cm}$ in diameter by $16 \mathrm{~cm}$ long) containing $50 \%$ soil by volume (Kennebeck silty clay loam) and $50 \%$ vermiculite. The tubes were completely randomized in the appropriate number of racks (100 tubes/rack). Testing of $F_{1} S$ and $F_{2} S$ involved three runs (except for Heyne [female] crossed with KS96WGRC39, which had two runs) of about 40 seed of each reciprocal cross and each parent in each run. All runs of experiments produced similar results and were combined. In the $\mathrm{F}_{3}$ generation, 10 tubes per line and eight lines per rack with their parents were planted. In all, 192 lines of Betty $\times$ Larned (three runs) and 128 lines of Heyne $\times$ KS96WGRC39 (two runs) were tested and the reaction of each $\mathrm{F}_{3}$ line determined by the mean of 10 plants. The $\mathrm{F}_{3}$ lines of the Betty $\times$ Larned cross were tested twice. All experiments were conducted in the greenhouse $(20 \pm$ $5^{\circ} \mathrm{C}$ ) with supplementary lighting from high-pressure sodium lamps $(400 \mathrm{~W})$ to provide a 16-h photoperiod (about $200 \mu \mathrm{E}$ $\mathrm{m}^{-2} \mathrm{~s}^{-1}$ ). All seedlings were watered everyday and fertilized once with water-soluble N-P-K (20:20:20) within 1 week after

Inoculum preparation. A single-spore, virulent isolate of $S$. nodorum (NOD-99), obtained from diseased wheat leaves colplanting.

lected from a commercial field in 1999 and stored in soil at $4^{\circ} \mathrm{C}$, was used throughout this study. Fungal spores from 7- to 10 day-old cultures on V8 juice agar $(150 \mathrm{ml}$ of $\mathrm{V} 8$ juice, $3 \mathrm{~g}$ of $\mathrm{CaCo}_{3}, 15 \mathrm{~g}$ of agar, and $850 \mathrm{ml}$ of distilled water) were streaked onto fresh V8 agar in petri dishes at room temperature $\left(22 \pm 2^{\circ} \mathrm{C}\right)$ and placed $40 \mathrm{~cm}$ below four cool-white fluorescent tubes (40W, about $36 \mu \mathrm{E}^{-2} \mathrm{~s}^{-1}$ ). After 7 days of growth, spores were harvested by blending a single agar plate in $200 \mathrm{ml}$ of distilled water with a commercial blender and resulting suspensions were filtered through two layers of cheesecloth. Unflavored gelatin $(0.5 \mathrm{~g})$ was dissolved in 20 $\mathrm{ml}$ of warm distilled water and added per $100 \mathrm{ml}$ of spore suspension as a spreader sticker. Spores were counted with a hemacytometer and suspensions adjusted using distilled water to $4 \times 10^{5}$ spores $/ \mathrm{ml}$.

Inoculation procedure. Plants (fourleaf stage) were inoculated 4 weeks after planting by spraying the fungal spore suspensions (35 ml/120 plants) onto leaves with an atomizer (De Vilbiss Co., Somerset, PA) operated at $69 \mathrm{kPa}$. Inoculated plants were air dried for about $30 \mathrm{~min}$ to allow spores to adhere to the leaves. After inoculation, the plants were placed in a plastic-covered mist chamber in a greenhouse $\left(25 \pm 5^{\circ} \mathrm{C}\right)$ for $72 \mathrm{~h}$ to maintain continual leaf wetness and then returned to the greenhouse bench. Mist was provided by two centrifugal atomizing humidifiers electrically controlled to operate for $1 \mathrm{~min}$ every $10 \mathrm{~min}$.

Disease assessments. Although plants at the four-leaf stage were inoculated, symptoms only occurred on the bottom three leaves. Even on susceptible cultivars, young leaves are highly resistant. Therefore, the bottom three leaves of each plant

Table 2. Crossing scheme for three moderately resistant (MR) and three susceptible (S) winter wheat cultivars used in greenhouse tests to assess the inheritance of resistance

\begin{tabular}{lcccccc}
\hline & \multicolumn{6}{c}{ Female parent } \\
\cline { 2 - 6 } Male parent & Betty & Heyne & $\mathbf{2 1 6 3}$ & Larned & KS96WGRC39 & Newton \\
\hline Betty (MR) & $\ldots$ & $\mathrm{X}$ & $\mathrm{X}$ & $\mathrm{X}$ & $\ldots$ & $\ldots$ \\
Heyne (MR) & $\mathrm{X}$ & $\ldots$ & $\mathrm{X}$ & $\ldots$ & $\mathrm{X}$ & $\ldots$ \\
$2163(\mathrm{MR})$ & $\mathrm{X}$ & $\mathrm{X}$ & $\ldots$ & $\ldots$ & $\ldots$ & $\ldots$ \\
Larned (S) & $\mathrm{X}$ & $\ldots$ & $\ldots$ & $\ldots$ & $\ldots$ & $\ldots$ \\
KS96WGRC39 (S) & $\ldots$ & $\mathrm{X}$ & $\ldots$ & $\ldots$ & $\ldots$ & $\ldots$ \\
Newton (S) & $\ldots$ & $\ldots$ & $\mathrm{X}$ & $\ldots$ & $\ldots$ & $\ldots$ \\
\hline
\end{tabular}

Table 1. Leaf reactions to Stagonospora nodorum for Kansas winter wheat lines in the seedling stage in the greenhouse

\begin{tabular}{llcc}
\hline Parent & \multicolumn{1}{c}{ Pedigree $^{\mathbf{a}}$} & Disease (\%) $^{\mathbf{b}}$ Reaction $^{\mathbf{c}}$ \\
\hline Betty & Jagger (KS82W418/Stephens) (KS, 1994) 'Sib' selection (KS, 1998) & $26.5(9)$ & MR \\
Heyne & Plainsman V/KS75216//SWM 754308/3/Plainsman V/Lindon//KS82W422 (KS, 1998) & $21.8(17)$ & MR \\
2163 & Pioneer line W558/5/Etoile de Choisy//Thorne/Clarkan/3/CI15342/4/Purdue 4946A4-18-2 (KS, 1989) & $27.7(11)$ \\
Larned & Scout*5/Ottawa (KS, 1976) & $54.2(18)$ & MR \\
KS96WGRC39 & TAM 107*3/TA2460 (Aegilops tauschii) & $52.8(1)$ & S \\
Newton & Pitic 62/Chris sib//2*Sonora 64/ Klein Rendidor/4/Scout (KS, 1977) & $49.3(9)$ & S \\
\hline
\end{tabular}

a State and year of release in parentheses; KS = Kansas.

${ }^{\mathrm{b}}$ Percentage leaf area affected. Numbers in parentheses indicate number of replicated experiments conducted in the greenhouse to determine reaction to Stagonospora nodorum leaf blotch with 40 plants per experiment.

${ }^{\mathrm{c}} \mathrm{MR}=$ moderately resistant and $\mathrm{S}=$ susceptible. 
were rated for percentage of leaf area covered by chlorosis and necrosis 14 days after inoculation. Each leaf was placed into one of the following categories: 0,1 , $5,10,25,50,75$, and $100 \%$ of leaf area affected (11). For each plant, the percentages of infection on three leaves were averaged. To give a final disease score for a plant, the average percentage of infection was divided by the average percentage of infection of the most susceptible plant in a rack. These final disease scores were used in the analysis of variance. For the $F_{3}$ generation, 30 leaves per line were averaged.

Genetic analysis. To determine the phenotypic ratio, the $F_{2}$ plants for all crosses were placed into two groups: (i) a susceptible group (S), consisting of plants with the percentage of infection greater than the mean of the susceptible parent (or the susceptible control for the cross between two moderately resistant cultivars) minus two standard errors; and (ii) the remaining group, consisting of resistant and intermediate $(\mathrm{R}+\mathrm{I})$ plants. The $\mathrm{F}_{3}$ lines were classified into three groups: (i) an $\mathrm{S}$ group, consisting of plants with the percentage of infection greater than the mean of the susceptible parent minus two standard errors; (ii) an $\mathrm{R}$ group, consisting of plants with the percentage of infection less than the mean of the resistant parent plus two standard errors; and (iii) the remaining lines, grouped into an I group.

Statistical analysis. Statistical analyses were conducted using PC SAS (SAS version 8.0; SAS Institute, Cary, NC). To determine differences between the parents and the $\mathrm{F}_{1} \mathrm{~s}$, as well as $\mathrm{F}_{2} \mathrm{~s}$ for moderately resistant $\times$ moderately resistant crosses, the mean values of Stagonospora nodorum blotch infection were compared by the general linear model analysis of variance (ANOVA) followed by mean separation by least significant difference (LSD, $P=$ 0.05). For the $\mathrm{F}_{3}$ lines of the cross Betty $\times$ Larned, the correlation coefficient $r$ was calculated to test the strength of the relationship between experiments 1 and 2. For the $F_{2}$ and $F_{3}$ generations, $\chi^{2}$ analyses were carried out to test the goodness-of-fit of the observed distribution with expected segregation ratios. To compare the difference between the percentage of $\mathrm{F}_{2}$ plants of the cross Betty $\times$ Heyne and the two parents in the susceptible group, a one-tailed $t$ test was performed.

\section{RESULTS}

The mean values of Stagonospora nodorum blotch infection in the $F_{1}$ plants and parents indicated a wide separation between Betty and Larned (Table 3). Similarly, the range of Stagonospora nodorum blotch infection on individual plants also showed that Betty (0 to 58\%) and Larned (51 to 100\%) had minimal overlap (Fig. 1). According to the ANOVA, the means of the $F_{1}$ plants from the cross Betty $\times$ Larned were not significantly different from that of Betty (Table 3). Therefore, resistance in cv. Betty was dominant. The means of each reciprocal indicated that there was no cytoplasmic effect (Table 3 ). The $\mathrm{F}_{2}$ generation of Betty $\times$ Larned segregated in a ratio of 3.8:1 (R+I:S). The observed phenotypic ratio was not significantly different from the ratio expected for a single dominant gene (Table 4). In the first test of the Betty $\times$ Larned $\mathrm{F}_{3}$ lines (Fig. 2, Exp. 1), 38 lines were classified as R, 39 as $\mathrm{S}$, and 90 as I. The observed ratio was not significantly different from the ratio expected for a single dominant gene $\left(\chi^{2}=1.02, P>\right.$ 0.50 ; experiment 1; Table 5). In the second test (Fig. 2, Exp. 2), there were 53 R, 41 S, and 97 I lines. Again, the observed ratio was not significantly different from the ratio expected for a single dominant gene $\left(\chi^{2}=1.56, P>0.25\right.$; experiment 2 ; Table $5)$. The means of $F_{3}$ lines from experiment 1 were highly correlated $(r=0.77, P<$ 0.0001 ) with those of experiment 2.

Mean separation for Heyne and KS96WGRC39 was relatively narrow in the experiment involving $F_{1} s$, because the level of resistance in Heyne was lower than that of Betty or 2163, and KS96WGRC39 was not as highly susceptible as Larned (Table 3). The frequency distribution of Stagonospora nodorum blotch infection on individual plants showed that there was broad overlap between Heyne and KS96WGRC39 (Fig. 3). According to the ANOVA, the means of the $F_{1}$ plants from the cross Heyne $\times$ KS96WGRC39 were not significantly different from that of Heyne (Table 3). Therefore, resistance in cv. Heyne was dominant. The means of each reciprocal indicated that there was no cytoplasmic effect (Table 3 ). The $\mathrm{F}_{2}$ generation of Heyne $\times$ KS96WGRC39 segregated in a ratio of $3.1: 1(\mathrm{R}+\mathrm{I}: \mathrm{S})$. The observed phenotypic ratio was not significantly different from the ratio expected for a single dominant gene (Table 4). In the $F_{3}$ test of the Heyne $x$

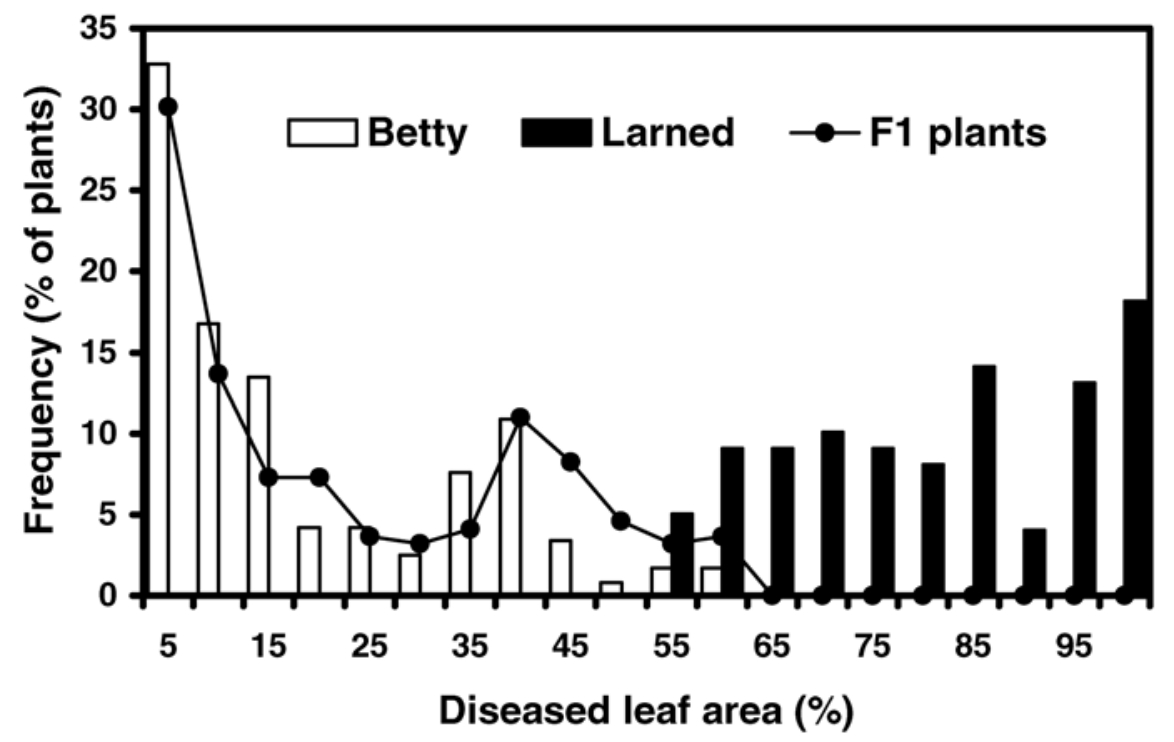

Fig. 1. Frequency distribution of percentage diseased leaf area for Stagonospora nodorum leaf blotch in winter wheat cvs. Betty and Larned and their $\mathrm{F}_{1}$ progeny.

Table 3. Mean percentage of diseased leaf area for Stagonospora nodorum leaf blotch for moderately resistant (MR) and susceptible (S) parents and their $F_{1}$ progeny ${ }^{\mathrm{a}}$

\begin{tabular}{|c|c|c|c|c|c|}
\hline \multirow[b]{2}{*}{ Cross } & \multicolumn{2}{|c|}{ Parent } & \multicolumn{2}{|c|}{$F_{1}$ plants } & \multirow[b]{2}{*}{$\mathbf{L S D}^{\mathbf{d}}$} \\
\hline & MR & $\mathbf{S}$ & $\mathbf{M R} \times \mathbf{S}^{\mathbf{b}}$ & $\mathbf{S} \times \mathbf{M R}^{\mathrm{c}}$ & \\
\hline Betty (MR) × Larned (S) & $21.1(119)$ & $81.3(99)$ & $20.5(111)$ & $20.0(109)$ & 6.4 \\
\hline Heyne $($ MR) $\times$ KS96WGRC39 (S) & $31.6(80)$ & $53.3(79)$ & $31.0(79)$ & $34.3(80)$ & 8.1 \\
\hline $2163(\mathrm{MR}) \times$ Newton $(\mathrm{S})$ & $20.3(118)$ & $52.8(117)$ & $39.5(118)$ & $41.7(117)$ & 6.9 \\
\hline
\end{tabular}

a Number in parentheses $=$ total number of plants tested.

b MR parent was used as a female in the cross.

c $\mathrm{S}$ parent was used as a female in the cross.

${ }^{\mathrm{d}}$ Least significant difference. 
KS96WGRC39 cross (Fig. 4), 52 lines were classified as R, 27 as S, and 37 as I. The observed ratio of the $\mathrm{F}_{3}$ lines failed the test for goodness-of-fit for the 1:2:1 ratio expected for a single dominant gene $(P<$ 0.001; Table 5).

A broad overlap between 2163 and Newton was observed in the frequency distribution of percent infection of individual plants (Fig. 5). The means of the $F_{1}$ plants from the cross $2163 \times$ Newton were intermediate between the two parents and were significantly different from that of both parents (Table 3 ). This indicated that there was no dominance to resistance in the cv. 2163. The ratio observed for the $F_{2}$ plants from the cross $2163 \times$ Newton did not fit the ratio expected for a single dominant gene $(P<0.001$; Table 4$)$.

To determine whether the moderately resistant parents shared any resistance genes, three moderately resistant cultivars were intercrossed in all possible combinations. When crossing two resistant parents, each carrying an independent single dominant gene for resistance, the following patterns potentially could occur: (i) if the genes in both parents are the same, no segregation will be observed and (ii) if the genes in both parents are different and unlinked, the $F_{2}$ populations will segregate with 1 out of $16 \mathrm{~F}_{2}$ plants carrying no resistant genes. Therefore, $6.25 \%$ of the individual $\mathrm{F}_{2} \mathrm{~S}$ should be significantly more susceptible than either parent.

Compared with both moderately resistant parents, the mean percentage of Stagonospora nodorum blotch infection in the $\mathrm{F}_{1} \mathrm{~s}$ from all moderately resistant $\times$ moderately resistant crosses was not significantly different from the mean of both parents (Table 6). Cytoplasmic effects were not detected. In the $\mathrm{F}_{2}$ generation, the mean values of the $F_{2}$ plants from the cross Betty $\times$ Heyne were not significantly different from the mean of both parents. However, the frequency of plants with disease infection greater than $73.5 \%$ (mean of the susceptible control Larned minus two standard errors) in the $F_{2}$ populations was $8.4 \%$. The frequencies of Betty and Heyne were 3.4 and $3.6 \%$, respectively (Fig. 6). According to the one-tailed $t$ test, the difference between the $F_{2}$ plants and the parents in the susceptible group was significantly different from zero. Further allelism tests for other crosses were not analyzed because of the failure to estimate the number of resistance genes in cv. 2163.

\section{DISCUSSION}

Selecting for green leaf duration has significantly improved the level of resistance in popular Kansas cultivars to Stagonospora nodorum leaf blotch (1). Our data quantified the magnitude of this improvement in the greenhouse environment where moderately resistant cultivars showed 20 to $32 \%$ diseased leaf area compared with $81 \%$ for a susceptible cultivar (Table 3). The main goal of this research was to determine how this moderate level of resistance was inherited and whether certain Kansas cultivars share a common gene for resistance.

All of our experiments were conducted in the greenhouse with seedling plants at the four-leaf stage. Several parameters can be used to estimate resistance to Stagonospora nodorum blotch, including incubation period; latent period; infection frequency; size, shape, and rate of lesion growth; and spore production and its rate of increase $(9,21,24)$. To eliminate the

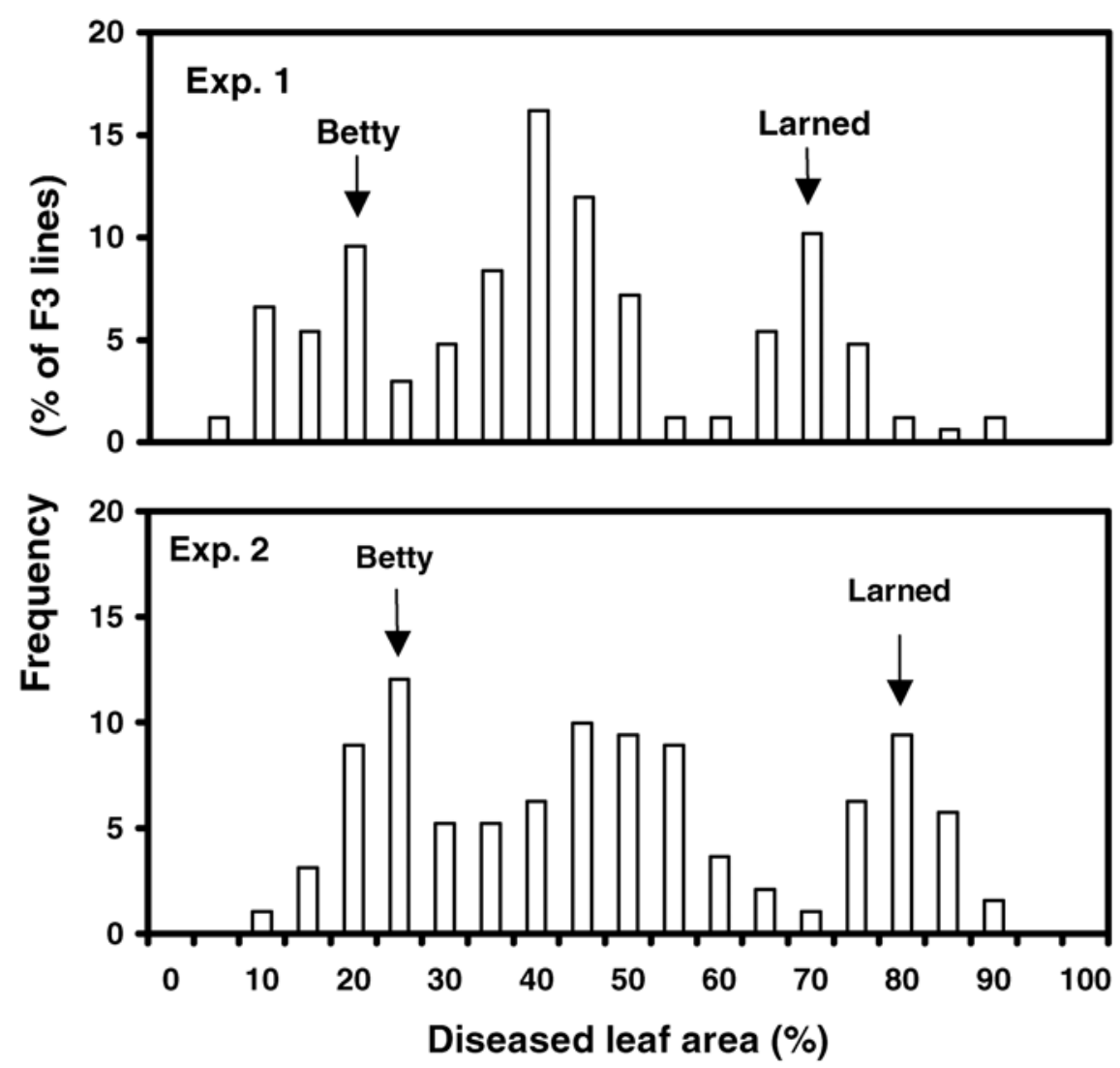

Fig. 2. Frequency distribution of $\mathrm{F}_{3}$ lines for percentage Stagonospora nodorum leaf blotch for Betty crossed with Larned in two separate experiments. The level of the parents also is indicated.

Table 5. Phenotypic ratios for reaction to Stagonospora nodorum leaf blotch in $\mathrm{F}_{3}$ lines from moderately resistant $(\mathrm{MR}) \times$ susceptible $(\mathrm{S})$ crosses and their goodness-of-fit tests with the ratio expected for a single dominant gene

\begin{tabular}{|c|c|c|c|c|c|}
\hline \multirow[b]{2}{*}{ Cross } & \multicolumn{3}{|c|}{ Observed ratio (no. of $F_{3}$ lines) ${ }^{a}$} & \multicolumn{2}{|c|}{ Expected ratio $(1: 2: 1)$} \\
\hline & $\mathbf{R}$ & I & $\mathbf{S}$ & $\chi^{2}$ & $P$ value \\
\hline Betty $\times$ Larned (experiment 1$)$ & 38 & 90 & 39 & 1.02 & $0.75-0.50$ \\
\hline Betty $\times$ Larned (experiment 2 ) & 53 & 97 & 41 & 1.56 & $0.50-0.25$ \\
\hline Heyne $\times$ KS96WGRC39 & 52 & 37 & 27 & 26.0 & $<0.001$ \\
\hline
\end{tabular}

${ }^{a} \mathrm{R}=$ resistant and $\mathrm{I}=$ intermediate.

Table 4. Phenotypic ratios for reaction to Stagonospora nodorum leaf blotch in the $\mathrm{F}_{2}$ plants from moderately resistant $(\mathrm{MR}) \times$ susceptible $(\mathrm{S})$ crosses and their goodness-of-fit tests with the ratio expected for a single dominant gene

\begin{tabular}{|c|c|c|c|c|c|}
\hline \multirow[b]{2}{*}{ Cross } & \multicolumn{2}{|c|}{ Observed ratio (number of $F_{2}$ plants) } & \multirow[b]{2}{*}{ Segregation ratio } & \multicolumn{2}{|c|}{ Expected ratio (3:1) } \\
\hline & $\mathbf{R}+\mathbf{I}^{\mathbf{a}}$ & $\mathbf{S}$ & & $\chi^{2}$ & $P$ value \\
\hline Betty $\times$ Larned & 190 & 50 & $3.8: 1$ & 2.20 & $0.25-0.10$ \\
\hline Heyne $\times$ KS96WGRC39 & 99 & 32 & $3.1: 1$ & 0.02 & $0.90-0.75$ \\
\hline $2163 \times$ Newton & 106 & 114 & $0.9: 1$ & 84.4 & $<0.001$ \\
\hline
\end{tabular}

a $\mathrm{R}+\mathrm{I}=$ resistant and intermediate. 


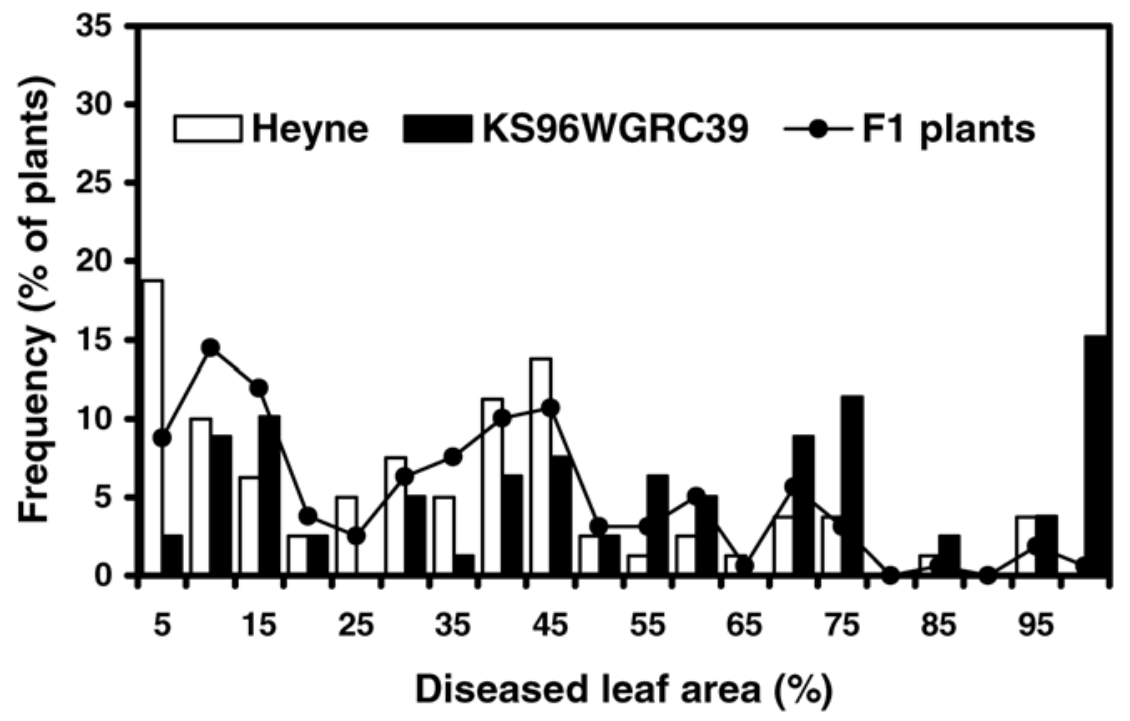

Fig. 3. Frequency distribution of percentage diseased leaf area for Stagonospora nodorum leaf blotch in winter wheat cvs. Heyne and KS96WGRC39 and their $\mathrm{F}_{1}$ progeny.

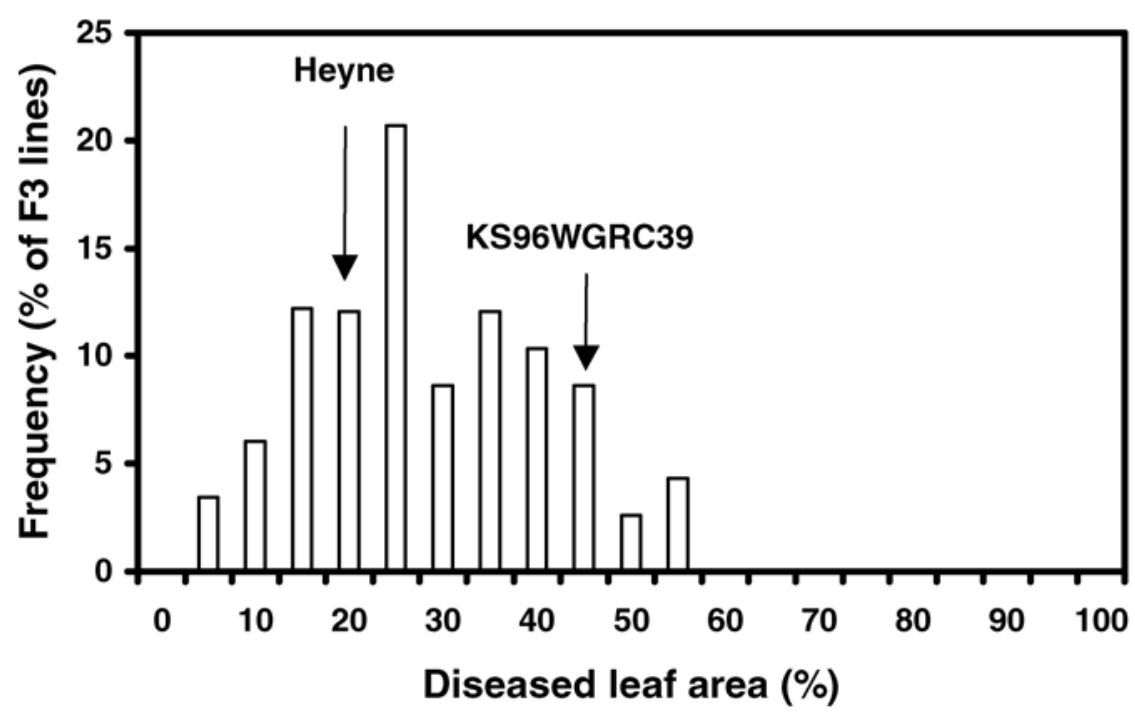

Fig. 4. Frequency distribution of $F_{3}$ lines for percentage Stagonospora nodorum leaf blotch for Heyne crossed with KS96WGRC39. The level of the parents also is indicated.

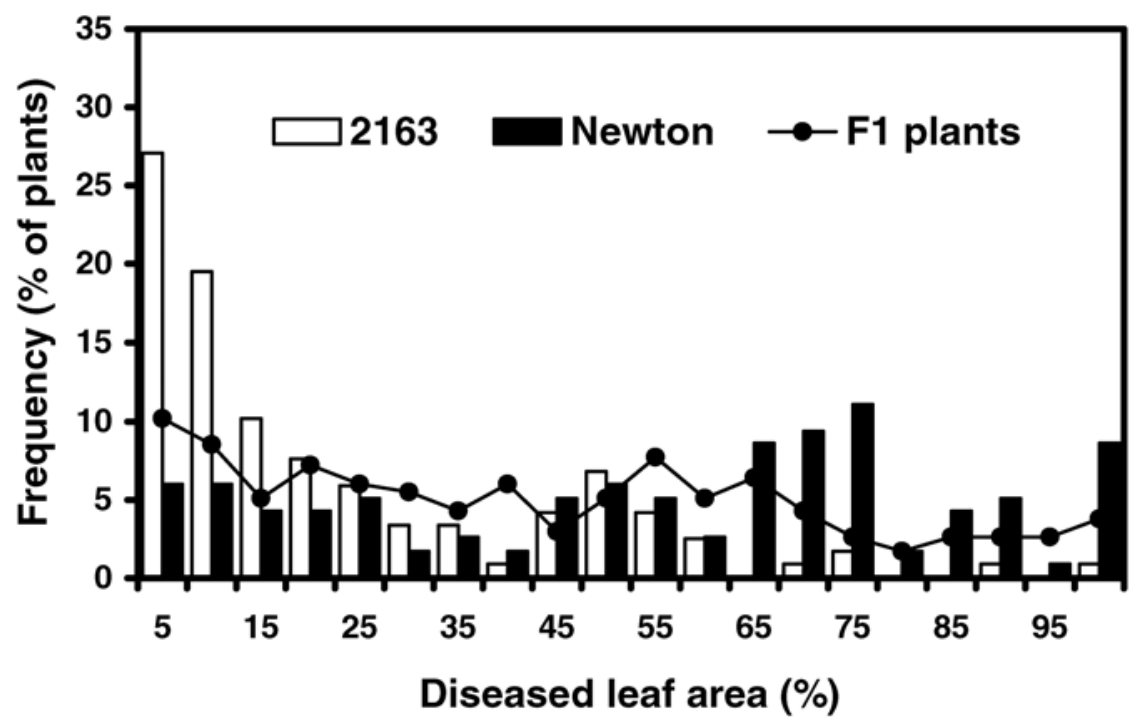

Fig. 5. Frequency distribution of percentage diseased leaf area for Stagonospora nodorum leaf blotch in winter wheat cvs. 2163 and Newton and their $F_{1}$ progeny. influence of plant height and maturity, seedling tests in a controlled environment such as a greenhouse or growth chamber often are used by measuring the percentage of infected leaf area $(29,37)$. Seedling tests in the greenhouse are reported to be highly correlated with field tests $(10,20,28)$. However, seedling test data reported here cannot be used for determining reactions to Stagonospora nodorum blotch on the heads because resistance to the leaf and head phases are under separate genetic control $(13,15,35)$.

Our experiments differed from those of Wong and Hughes (38) in scoring disease development for classification of segregating populations. They rated the disease severity on a 0 -to- 9 scale and classified 0 to 4 as a resistant group and 5 to 9 as a susceptible group. However, in this study, plants were rated by using percentage of leaf area affected (0 to 100\%) and disease scores were continuous, with overlap between resistant and susceptible parents. Significant overlap existed between the parents of most crosses we tested. This phenomenon also was detected in the field (17) and in the greenhouse (2). In preliminary testing of the parental lines, the disease scores among the parents were separable without any overlap when at least 10 plants per line were averaged. In this case, plants with little, or no, disease (escapes) are compensated for by plants that may produce above-average disease. However, for our data, the disease reaction of individual plants in the $F_{2}$ generations showed large variation because of segregation and the lack of this 10-plant replication.

The disease reactions of $F_{1}$ plants from the two crosses Betty $\times$ Larned and Heyne $\times$ KS96WGRC39 demonstrate dominance for resistance. Cytoplasmic effects were not observed in all crosses we tested. Many other studies also have found no cytoplasmic effects $(2,24)$ even though Nelson (25) suggested that cytoplasmic effects might be involved in some sources of Stagonospora nodorum blotch resistance.

Testing of $\mathrm{F}_{2} \mathrm{~S}$ from the cross Heyne $\times$ KS96WGRC39 indicated that Heyne may carry a gene of large effect. However, the phenotypic ratio obtained from the $116 \mathrm{~F}_{3}$ lines did not fit a ratio for single dominant gene segregation. There are several possible reasons for the failure to estimate the number of resistant genes from the $\mathrm{F}_{3}$ testing. First, the number of $F_{3}$ lines was somewhat small to separate the segregating lines from the $\mathrm{R}$ group compared with that of Betty $\times$ Larned cross $\left(192 \mathrm{~F}_{3}\right.$ lines $)$. Second, to increase the probability up to $99 \%$ to correctly categorize the segregating lines, 16 plants per line, instead of 10 , would be needed. Although the segregation ratio obtained from the $\mathrm{F}_{3}$ lines (52:37:27 $\mathrm{R}$ :segregating:S) did not fit the ratio expected for a single dominant gene (1:2:1), when the $\mathrm{R}$ and segregating lines were 
Table 6. Mean percentage diseased leaf area for Stagonospora nodorum leaf blotch for moderately resistant parents and their $\mathrm{F}_{1}$ progeny ${ }^{\mathrm{a}}$

\begin{tabular}{|c|c|c|c|c|c|c|c|}
\hline \multirow[b]{2}{*}{ Type of cross $(A \times B)$} & \multicolumn{4}{|c|}{ Parent $^{\text {b }}$} & \multicolumn{2}{|c|}{$F_{1}$ plants } & \multirow[b]{2}{*}{$\mathbf{L S D}^{\mathbf{e}}$} \\
\hline & A & B & Mean & $\mathbf{S}$ & $\mathbf{A} \times \mathbf{B}^{\mathbf{c}}$ & $\mathbf{B} \times \mathbf{A}^{\mathbf{d}}$ & \\
\hline Betty $\times$ Heyne & $37.0(40)$ & $48.8(40)$ & $42.9(80)$ & $66.7(40)$ & $39.0(40)$ & $41.2(40)$ & 10.7 \\
\hline Betty $\times 2163$ & $34.0(40)$ & $40.7(40)$ & $37.3(80)$ & $61.4(40)$ & $36.5(40)$ & $37.1(40)$ & 11.1 \\
\hline Heyne $\times 2163$ & $25.6(40)$ & $40.1(40)$ & $32.8(80)$ & $63.3(40)$ & $32.5(40)$ & 30.7 (40) & 11.0 \\
\hline
\end{tabular}

a Number in parentheses $=$ total number of plants tested.

${ }^{\mathrm{b}} \mathrm{A}=$ moderately resistant parent $\mathrm{A}, \mathrm{B}=$ moderately resistant parent $\mathrm{B}$, and $\mathrm{S}=$ susceptible control; Larned for the crosses Betty $\times$ Heyne and Betty $\times 2163$, and Newton for Heyne $\times 2163$.

c Moderately resistant parent A was used as a female in the cross.

${ }^{\mathrm{d}}$ Moderately resistant parent B was used as a female in the cross.

e Least significant difference.

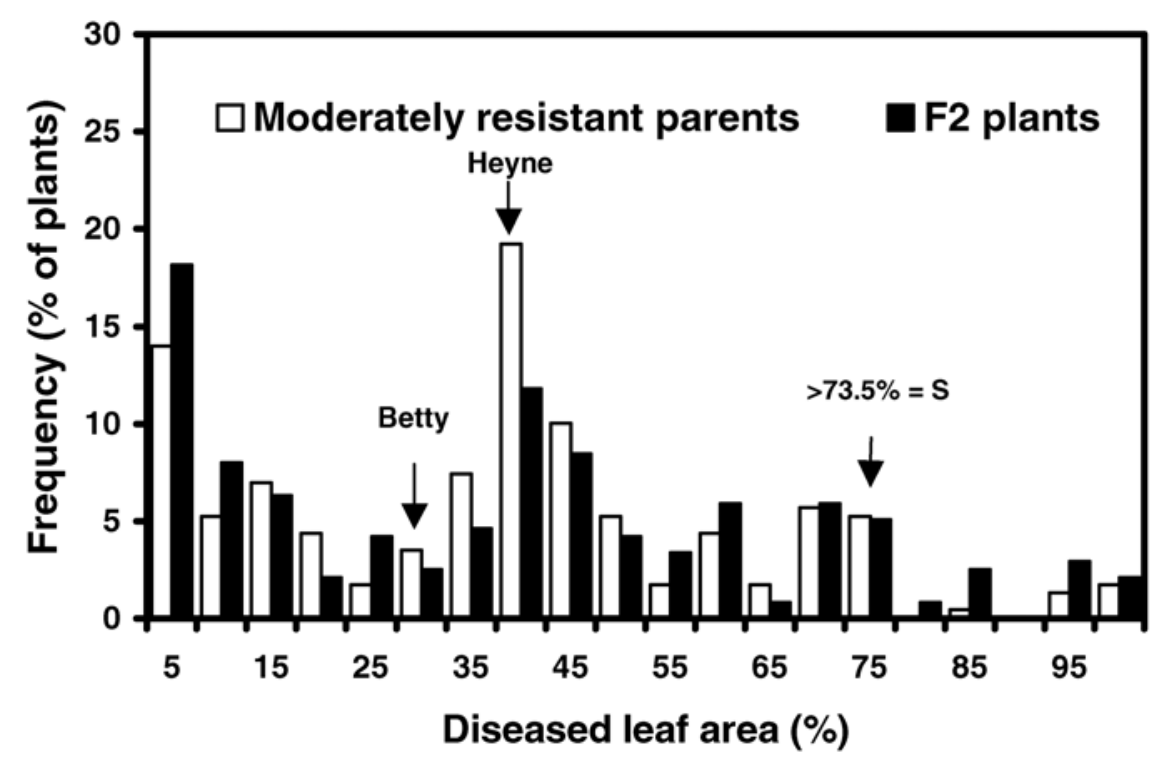

Fig. 6. Frequency distribution of $F_{2}$ plants for percentage Stagonospora nodorum leaf blotch in the cross of two moderately resistant cultivars (Betty and Heyne) and the average of the two parents. The susceptible class is any value greater than $73.5 \%$ (mean of the susceptible control Larned minus two standard errors). The level of the parents also is indicated.

combined, the ratio (3.3:1) was close to $3: 1$. Finally, the disease ratings of the parents Heyne and KS96WGRC39 were relatively close to each other. The difference of Stagonospora nodorum blotch infection between Heyne and KS96WGRC39 was only $23.8 \%$ compared with $60.2 \%$ between Betty and Larned. In addition, some overlap existed between Heyne and KS96WGRC39, which made the separation of each category difficult (23). Nevertheless, genetic results obtained from the cross Heyne $\times$ KS96WGRC39 suggested that Heyne may carry a gene of large effect on resistance to the leaf phase of Stagonospora nodorum blotch.

In the $F_{2}$ testing from the cross $2163 \times$ Newton, the observed segregation ratio failed the test for a single gene for resistance. Because of the large variances within the parents and a wide overlap between the parents, the number of genes controlling resistance to Stagonospora nodorum blotch could not be estimated. Another reason for failure to determine the number of genes is because the level of resistance in cv. 2163 was not as high as that of Betty or Heyne in most experiments (Tables 1 and 6), and cv. Newton was not as highly susceptible as Larned (Table 3). Otherwise, resistance in 2163 may be polygenic.

In the allelism tests, the $F_{2}$ mean from the cross Betty $\times$ Heyne was not significantly different from that of either parent. However, the frequency comparison between the $F_{2}$ populations and the average of both parents revealed that the resistance gene in cv. Betty probably is not an allele of the gene in Heyne.

Breeding for resistance to Stagonospora nodorum leaf blotch can reduce the secondary infection and slow disease development (2). Resistance to Stagonospora nodorum leaf blotch in the Kansas winter wheat cv. Betty appears to be controlled by a single dominant gene. Although Scharen and Eyal (30) reported that resistance to Stagonospora nodorum blotch might be controlled by the additive action of several genes in moderately resistant cultivars, our results with Betty were similar to those of Frecha (12) with cv. Atlas 66. Further work is needed to identify the chromosomal location of the resistance gene. Additionally, it appears that a gene different from that in Betty is responsible for the resistance observed in Heyne. Having more than one gene deployed in Kansas is important in case a new race of the fungus develops. This information should be useful to wheat breeding programs interested in development of resistance to Stagonospora nodorum leaf blotch.

\section{LITERATURE CITED}

1. Bockus, W. W., Appel, J. A., Bowden, R. L. Fritz, A. K., Gill, B. K., Martin, T. J., Sears, R. G., Seifers, D. L., Brown-Guedira, G. L., and Eversmeyer, M. G. 2001. Success stories: Breeding for wheat disease resistance in Kansas. Plant Dis. 85:453-461.

2. Bostwick, D. E., Ohm, H. W., and Shaner, G. 1993. Inheritance of Septoria glume blotch resistance in wheat. Crop Sci. 33:439-443.

3. Cunfer, B. M., and Ueng, P. P. 1999. Taxonomy and identification of Septoria and Stagonospora species on small-grain cereals. Annu. Rev. Phytopathol. 37:267-284.

4. Doodson, J. K. 1981. The economic contribution of resistant winter wheat varieties. J. Natl. Agric. Bot. 15:413-420.

5. Ecker, R., Cahaner, A., and Dinoor, A. 1990. The inheritance of resistance to Septoria nodorum blotch. II. The wild wheat species Aegilops speltoides. Plant Breed. 104:218-223.

6. Ecker, R., Cahaner, A., and Dinoor, A. 1990. The inheritance of resistance to Septoria nodorum blotch. III. The wild wheat species Aegilops longissima. Plant Breed. 104:218223.

7. Ecker, R., Dinoor, A., and Cahaner, A. 1989. The inheritance of resistance to Septoria glume blotch. I. Common bread wheat, Triticum aestivum. Plant Breed. 102:113-131.

8. Eyal, Z. 1981. Integrated control of Septoria diseases of wheat. Plant Dis. 65:763-768.

9. Eyal, Z. 1999. Breeding for resistance to Septoria and Stagonospora diseases in wheat. Pages 332-344 in: Septoria in Cereals: A Study of Pathosystems. J. A. Lucas, P. Bowyer, and H. M. Anderson, eds. CABI Publishing, Wallingford, UK

10. Eyal, Z., and Scharen, A. L. 1977. A quantitative method for the inoculation of wheat seedlings with pycnidiospores of Septoria nodorum. Phytopathology 67:712-714.

11. Eyal, Z., Scharen, A. L., Prescott, J. M., and van Ginkel, M. 1987. The Septoria Diseases of Wheat: Concepts and Methods of Disease Management. CIMMYT, Mexico, D.F.

12. Frecha, J. H. 1973. The inheritance of resistance to Septoria nodorum in wheat. Bol. Genet. Inst. Fitotec. Castelar 8:29-30.

13. Fried, P. M., and Meister, E. 1987. Inheritance of leaf and head resistance of winter wheat to Septoria nodorum in a diallel cross. Phytopathology 77:1371-1375.

14. Hewett, P. D. 1975. Septoria nodorum on seedlings and stubble of winter wheat. Trans. Br. Mycol. Soc. 65:7-18.

15. Hu Xueyi, Bostwick, D., Sharma, H. Ohm, H., and Shaner, G. 1996. Chromosome and chromosomal arm locations of genes for resistance 
to Septoria glume blotch in wheat cultivar Cotipora. Euphytica 91:251-257.

16. Jones, D. G., and Odebumni, K. 1971. The epidemiology of Septoria tritici and $S$. nodorum IV. The effect of inoculation at different growth stage and on different plant parts. Trans. Br. Mycol. Soc. 56(2):281-288.

17. Karjalainen, R. 1983. Inheritance of leaf resistance to Septoria nodorum Berk. in two crosses of spring wheat. J. Sci. Agric. Soc. Finl. 55:425-430.

18. King, J. E., Cook, R. J., and Melville, S. C. 1983. A review of Septoria diseases of wheat and barley. Ann. Appl. Biol. 103:345-374.

19. Kleijer, G., Fossati, A., and Paccand, F. Y. 1977. Chromosomal location of a dominant gene for resistance at the seedling stage to Septoria nodorum Berk. in wheat variety 'Atlas 66'. Z. Pflanzenzuecht. 78:170-173.

20. Krupinsky, J. M., Schillinger, J. A., and Scharen, A. L. 1972. Resistance in wheats to Septoria nodorum. Crop Sci. 12:528-530.

21. Lancashire, P. D., and Jones, D. G. 1985. Components of partial resistance to Septoria nodorum in winter wheat. Ann. Appl. Biol. 106:541-553.

22. Ma, H., and Hughes, G. R. 1993. Resistance to Septoria nodorum blotch in several Triticum species. Euphytica 70:151-157.

23. Ma, H., and Hughes, G. R. 1995. Genetic control and chromosomal location of Triticum timopheevii-derived resistance to Septoria nodorum blotch in durum wheat. Genome 38:332-338.

24. Mullaney, E. J., Martin, J. M., and Scharen, A L. 1982. Generation mean analysis to identify and partition the components of genetic resistance to Septoria nodorum in wheat. Euphytica 31: 539-545.

25. Nelson, L. R. 1980. Inheritance of resistance to Septoria in wheat. Crop Sci. 20:447-449.

26. Nelson, L. R., and Gates, C. E. 1982. Genetics of host plant resistance of wheat to Septoria nodorum. Crop Sci. 22:771-773.

27. Nicholson, P., Rezanoor, H. N., and Worland, A. J. 1993. Chromosomal location of resistance to Septoria nodorum in a synthetic hexaploid wheat determined by the study of chromosomal substitution lines in 'Chinese Spring' wheat. Plant Breed. 110:177-184.

28. Rufty, R. C., Hebert, T. T., and Murphy, C. F. 1981. Evaluation of resistance to Septoria nodorum in wheat. Plant Dis. 65:406-409.

29. Scharen, A. L., and Eyal, Z. 1980. Measurement of quantitative resistance to Septoria nodorum in wheat. Plant Dis. 64:492-496.

30. Scharen, A. L., and Eyal, Z. 1983. Analysis of symptoms on spring and winter wheat cultivars inoculated with different isolates of Septoria nodorum. Phytopathology 75:143-147.

31. Scharen, A. L., and Krupinsky, J. M. 1969. Effect of Septoria nodorum infection on $\mathrm{CO}_{2}$ absorption and yield of wheat. Phytopathology 59:1228-1301.
32. Tavella, C. M. 1978. Date of heading and plant height of wheat varieties as related to Septoria leaf blotch damage. Euphytica 27:577-580.

33. Tomerlin, J. R., El-Morshidy, M. A., Moseman, J. G., Baenziger, P. S., and Kimber, G. 1984. Resistance to Erysiphe graminis f. sp. tritici, Puccinia recondita f. sp. tritici, and Septoria nodorum in wild Triticum species. Plant Dis. 68:10-13.

34. Walther, H., and Bohmer, M. 1992. Improved quantitative-genetic selection in breeding for resistance to Septoria nodorum (Berk.) in wheat. J. Plant Dis. Prot. 99:371-380.

35. Wicki, W., Winzeler, M., Schmid, J. E., Stamp, P., and Messmer, M. 1999. Inheritance of resistance to leaf and glume blotch caused by Septoria nodorum Berk. in winter wheat. Theor. Appl. Genet. 99:1265-1272.

36. Wiese, M. V. 1987. Compendium of Whea Diseases. 2nd ed. American Phytopathological Society, St. Paul, MN

37. Wilkinson, C. A., Murphy, J. P., and Rufty, R. C. 1990. Diallel analysis of components of partial resistance to Septoria nodorum in wheat. Plant Dis. 74:47-50.

38. Wong, L. S. L., and Hughes, G. R. 1989 Genetic control of seedling resistance to Lep tosphaeria nodorum in wheat. Pages 136-137 in: Septoria of Cereals. Proc. Workshop Zurich, Switzerland. P. M. Fried, ed. Swiss Federal Research Station for Agronomy, ZurichReckenholz, Switzerland. 